\title{
New Trends in the Criminalization of Stalking in the EU Member States
}

\author{
Suzan van der $\mathrm{Aa}^{1}$ (D)
}

Published online: 20 September 2017

(C) The Author(s) 2017. This article is an open access publication

\begin{abstract}
Article 34 of the Council of Europe Convention on Preventing and Combating Violence against Women and Domestic Violence obliges signatory states to criminalize stalking. This article provides an inventory of criminal anti-stalking legislation in the $28 \mathrm{EU}$ Member States in order to see whether they live up to this obligation. Although the number of Member States with dedicated legislation has increased significantly $(n=21)$ there are some questionable trends, such as the proliferation of criminal provisions which require the victim to have experienced fear or distress or an inclusion of an exhaustive list of stalking tactics. Although the states are not in evident violation of article 34 their perception of what constitutes stalking sometimes deviates from the intentions of the Convention.
\end{abstract}

Keywords Stalking C Criminal law Criminalization - Council of Europe Convention on preventing and combating violence against women and domestic violence $\cdot$ EU member states

\section{Introduction $^{1}$}

Stalking can be defined as 'persistent harassment in which one person repeatedly imposes on another unwanted communications and/or contacts' (Mullen et al. 2001). What characterizes stalking is the repetitive or systematic nature of the behavior, aimed at a specific person, which is unwanted by the targeted person (Mullen et al. 2001; Van der Aa 2010). The behavior can be perceived by the victim as annoying, threatening, fear-inducing or disturbing.

Although stalking is an ancient phenomenon, it was not until the 1990 s before it was recognized as a criminal phenomenon in its own right. In reaction to the physical attacks of two famous actresses by their obsessed stalkers, the North-American state of California was

\footnotetext{
${ }^{1}$ A German version of this text will appear as a contribution in the following handbook: W. Ortiz-Müller (ed.), Praxis-Handbuch Stalking. Stuttgart: Kohlhammer (March 2017).
}

Suzan van der Aa

s.vdraa@tilburguniversity.edu

1 Tilburg Law School, INTERVICT, Tilburg University, Tilburg, Netherlands 
the first jurisdiction to create a specific criminal provision to deal with the problem more efficiently (California Penal Code, Section 646.9). The other American states quickly followed suit, and within three years, all states and the District of Colombia had special criminal antistalking laws in place. This Californian law also inspired foreign legislators around the world to criminalize the behavior, including countries such as Australia and Canada.

In many Member States of the European Union, however, the idea of legally codifying against stalking met with resistance and, as a result, many Member States of the European Union remained without dedicated national anti-stalking laws for a long time. Over the years, there have been some studies that aimed to make an inventory of national anti-stalking legislation within the EU Member States. The first of such studies was conducted in 2007 by the Modena Group on Stalking. According to their findings, only eight Member States had introduced specific anti-stalking legislation into their national legal systems (Modena 2007). The other Member States did not feel the need to pass specific legislation, because stalking was not considered a social problem and had not given rise to public debate. A second reason to abstain from adopting dedicated legislation was the conviction that generic criminal provisions — such as assault, threat or coercion - in combination with protection order schemes would provide adequate protection against the behavior.

Another factor that may have played a role in Europe's hesitance to criminalize the conduct is the strong criticism voiced by some influential criminal lawyers and legal philosophers who opposed the criminalization of stalking and their disagreement about the nature of the actual harm anti-stalking legislation ought to address (e.g., Ashworth et al. 2013; Guelke and Sorel 2016). The controversy on whether stalking warranted redress through criminal prosecution also influenced parliamentary debates, thereby delaying the coming into force of national legislation. ${ }^{2}$

Despite the controversy, by 2010, the number of Member States with criminal anti-stalking laws had already risen to 13 (Van der Aa and Römkens 2012; Kelly et al. 2010). It appeared that Europe was slowly but steadily warming up to the idea of stalking as a genuine crime in and of itself. A comparative study published in 2012 revealed, however, large national differences in their approach against stalking (Van der Aa and Römkens 2012). Stalking provisions varied, for instance, with respect to the inclusion of a (limitative) list of stalking tactics, requirements for prosecution, requisite mens rea on the part of the perpetrator and penalties imposed.

Meanwhile, important developments have taken place on the international and regional level that could further accelerate the dissemination of anti-stalking legislation across Europe, most notably the coming into force of the 2013 Council of Europe Convention on preventing and combating violence against women and domestic violence (hereafter: the Convention). This Convention was the first European regional human rights instrument to specifically address violence against women as a form of gender-based violence. Against that backdrop, it specifically calls upon signatory states to criminalize stalking (Article 34):

Parties shall take the necessary legislative or other measures to ensure that the intentional conduct of repeatedly engaging in threatening conduct directed at another person, causing her or him to fear for her or his safety, is criminalized.

The accompanying explanatory report to the Convention explains that 'the threatening behavior may consist of repeatedly following another person, engaging in unwanted communication with another person or letting another person know that he or she is

\footnotetext{
${ }^{2}$ For the long parliamentary history of the Dutch anti-stalking law see (Van der Aa 2010, p. 77-80). In Italy, it was debated whether criminalization would be in line with constitutional law (De Fazio 2011). The German antistalking law also met with resistance (Kraenz 2008, p. 281).
} 
being observed'. ${ }^{3}$ Other types of behavior are also mentioned in the report as examples of stalking tactics (e.g., vandalizing the property of another person, targeting a person's pet, creating false identities or spreading untruthful information online).

At the time of writing of this article - 25 May 2016 - all 28 EU Member States had signed the Convention, and in 14 Member States the Convention had already been ratified and entered into force. ${ }^{4}$ Only one EU Member State, Denmark, used its right to make reservations to Article 34 and to opt for non-criminal sanctions instead of criminal sanctions to counter stalking behavior. The option to make reservations for the articles 33 (psychological violence) and 34 (stalking) was foreseen in article 78 paragraph 3 of the Convention. This means that — with the exception of Denmark - all other EU Member States are obliged to adopt criminal anti-stalking provisions, now or in the near future.

The aim of this paper is twofold: First, to make an inventory of any legislative changes that have occurred since the last study on anti-stalking legislation in the EU Member States in 2010. With the help of a comparative study, the current state of affairs on anti-stalking legislation in the 28 EU Member States is mapped ('Trends in the criminalization of stalking in the EU member states'). Have more Member States passed on dedicated legislation during these past five years? If so, how have they defined stalking in their criminal laws, what approach have they adopted and which trends - if any - can be discerned? The second aim is to establish whether the EU Member States are living up to the obligations stemming from Article 34 of the Council of Europe Convention ('Conformity with article 34 of the Council of Europe Convention'). At the end, an overall conclusion is drawn in which recommendations are presented that can help Member States bring their national legislation up to par with international standards ('Conclusion').

\section{Trends in the criminalization of stalking in the $\mathrm{EU}$ member states}

\section{Method}

Before discussing the results, the methodology used to identify the legislative changes will first be described. In previous overview studies, national legal experts were invited to comment extensively on their respective legal systems. This time, however, there was no ongoing research project that allowed for such an approach. Instead, a mixed-method approach was used, combining online information with (brief) consultation of national legal experts.

As a first step, legal information readily available in open internet sources was consulted with the help of a primary search. This search involved typing in keywords such as 'stalking', 'law', 'legislation' or 'harassment' in combination with the names of the EU Member States into the Google search engine and looking for information that had appeared after $2010 .^{5}$ Both

\footnotetext{
${ }^{3}$ See explanatory report to the Council of Europe Convention on preventing and combating violence against women and domestic violence (CM (2011) 49 final) at: www.coe.int/conventionviolence.

${ }^{4}$ These Member States were Austria, Belgium, Denmark, Finland, France, Italy, Malta, the Netherlands, Poland, Romania, Slovenia, Spain, Sweden, and Portugal. In addition, the European Union itself will soon approve the text of the Council of Europe Convention adding even more (see the Proposal of 4 March 2016 for a Council Decision on the conclusion, by the European Union of the Council of Europe Convention on preventing and combating violence against women and domestic violence (Brussels COM(2016) 109 final).

${ }^{5}$ For the purpose of this study, anti-harassment laws were also considered anti-stalking measures, as long as their scope exceeded the work floor. Although harassment does not fully equate with stalking, some Member States place anti-harassment legislation in the stalking key. As long as the repetitive or systematic harassment of another person in general is criminalized, it will be considered as a form of anti-stalking legislation, regardless of the precise label that was used (more on the difference between stalking and harassment in paragraph 2.1.5).
} 
English keywords and translations of the keywords in the native language were used. Because the primary search mainly served to get a basic understanding of the legal situation in a particular country and to identify trustworthy materials, it was indiscriminate regarding the reliability of the initial ('gray') sources. This technique revealed press releases, reports, and news items discussing new laws or initiatives, albeit that law-specific details were mostly lacking (e.g., Valente 2014; Finland Times 2015; Balzan 2014).

The second step was to take the generic information from the 'gray' sources as a starting point, and then search official sources - such as national Criminal Codes, websites of Ministries of Justice, government websites - in order to obtain more reliable and in-depth information. Sometimes, the official sources could be consulted directly - for instance, when the native legal terminology or the location of the relevant provision in the Criminal Code was known from previous studies - but usually the circuitous approach via newspaper articles and press releases proved invaluable, not only to locate the appropriate authoritative sources, but also to collect relevant information that had not yet been codified or posted on official websites. Eventually, the information on all countries that were classified as having anti-stalking legislation could be traced back to authoritative sources, notably national Criminal Codes or dedicated Anti-Stalking Acts.

Obviously, an online search of domestic legislation involving 28 jurisdictions has serious limitations. Despite the fact that in this day and age a lot of news is mediatized and digitalized - especially information concerning important changes to criminal law - there is always a risk that in some countries these changes have not generated much (online) media coverage. The possibility of underreporting may have resulted in some countries being wrongfully classified as not having dedicated anti-stalking laws, while in reality they have. A second problem involved language and linguistic barriers. While English, German, Dutch, and French websites were accessible, the author's understanding of information in other native languages is more limited. Chances were that certain facts or legal technicalities had gotten 'lost in translation'.

The third step, therefore, involved the contacting of national legal experts and asking their help in: a) confirming or negating the findings derived from the internet search, b) translating the found national anti-stalking definitions in English, and c) disclosing whether there were any developments that pointed toward the criminalization of stalking in the near future. National legal experts were only contacted in two situations: 1) in case the internet search had not yielded a (semi)official translation of the anti-stalking provisions or 2) when there was no evidence of stalking having been criminalized. In the first case, the expert input was needed to obtain a more reliable translation of the criminal provision, in the second case, the expert was needed to confirm that stalking had indeed not been codified. Based on these criteria, a total of 18 legal experts were contacted with a request for help, of which 15 replied. $^{6}$ A (semi)official translation of the stalking provision was available online (see Appendix 2) for eight Member States. This approach only left the Danish, Luxembourg, and Cypriot jurisdictions unaccounted for. Of these three countries, Cyprus and Denmark did not have any dedicated anti-stalking legislation, but a recent press

\footnotetext{
${ }^{6}$ The author would like to thank Sara Thunberg (SE), Jens Henrichs (DE), Lachezar Yanev (BG), Reana Bezic (HR), Vadim Poleshchuk (EE), Laetitia Ruiz (FR), Efstratios Papanis (EL), Chiara Raucea (IT), Iveta Brinuma (LV), Rita Zukauskiene (LT), Slawomir Buczma (PL), Ana Ferreira (PT), Martin Buzinger (SK), Pomoc Obetiam Násilia (victim support Slovakia), Nina Persak (SL), and Ana Isabel Cerezo Domingues (ES) for their help in translating the national provisions. The Dutch and Belgian provisions were translated by the author herself.
} 
release published on the website of the Cypriot Ministry of Justice and Public Order reported of a new bill that is now before parliament. The national provision of Luxembourg was translated with the help of the author's non-native knowledge of French, and should therefore be interpreted with care.

When it comes to the substantive (content) analyses, these were mostly based on a close reading of the anti-stalking provisions. However, a correct interpretation of the constituent elements usually also depends on case law, national legal practice, and parliamentary documentation. There was no possibility to take into account all those additional sources. Also, the fact that relevant information consisted of legal jargon the interpretation and meaning of which often varies from state to state - could have had a bearing on the correctness of the interpretations as well. As a consequence, the results presented below, may not reflect the actual situation in a European Member State with $100 \%$ accuracy. $^{7}$

\section{Results}

\section{Significant increase in member states with a criminal provision}

The first finding is that during the past five years, the number of EU Member States that passed criminal anti-stalking legislation has risen significantly. At this moment, no less than 21 Member States have dedicated criminal provisions in place (see Appendix 1). Compared to the situation in 2010, when only ten Member States had criminalized the behavior, their number has increased substantially.

The seven countries that have not (yet) introduced stalking or harassment as a specific offense are: Bulgaria, Estonia, Denmark, Greece, Latvia, Lithuania, and Cyprus. Regarding the latter, the Cypriot Ministry of Justice and Public Order has stated in a press release that they are currently working on a draft bill as a result of signing the Council of Europe Convention. ${ }^{8}$ Furthermore, the Latvian legal expert, who was contacted to double-check the findings of the internet search, disclosed that Latvia will introduce direct criminal liability for stalking in the near future as well, again as a result of the Council of Europe Convention. So although multiple factors may have played a role in the current trend to criminalize stalking - e.g., a strong anti-stalking lobby, increased public and political awareness, heightened media attention, and critical reports by CEDAW - the Council of Europe Convention seems to have had a significant impact on national legislators' willingness to take action. ${ }^{9}$

A remarkable finding is that Denmark can no longer be considered a country that has criminalized stalking, at least not directly. Previous studies did classify Denmark as such (e.g., Van der Aa and Römkens 2012; De Fazio 2009). It was even considered the first country in the

\footnotetext{
${ }^{7}$ All suggestions to make the interpretation more accurate are highly appreciated and can be sent to s.vdraa@tilburguniversity.edu.

${ }^{8}$ See the press release on the website of the Cypriot Ministry of Justice and Public Order of 5 January 2017 in which they report that the bill has now proceeded to the House of Representatives for approval (http://www.mjpo. gov.cy/mjpo/mjpo.nsf/Al1/54B7BD4A259EF153C22580A5003FFA9E?OpenDocument\&highlight=stalking, last accessed 27 March 2017).

${ }^{9}$ In fact, Portuguese news bulletins also mention the statutory obligation under the Convention as an important contributing factor (Valente 2014). For Cyprus, the Convention was a source of inspiration as well (see http://www.mjpo.gov.cy/mjpo/mjpo.nsf/A11/54B7BD4A259EF153C22580A5003FFA9 E?OpenDocument\&highlight=stalking).
} 
EU to have criminalized stalking based on article 265 that was introduced in the Danish Criminal Code as early as 1933 . This article read that:

Any person who violates the peace of some other person by intruding on him, pursuing him with letters or inconveniencing him in any other similar way, despite warnings by the police, shall be liable to a fine or to imprisonment for a term not exceeding 2 years. A warning under this provision shall be valid for five years.

This provision was already somewhat ambiguous as to what behavior was criminalized exactly. Was it the intrusive behavior against another person that warranted a criminal justice reaction, or was it the fact that the perpetrator had acted against specific instructions from the police, and had shown contempt of police authority? Also, were the warnings by the police an absolute prerequisite (conditio sine qua non) for prosecution or was the public prosecutor in serious cases allowed to bring perpetrators to justice, regardless of whether (s)he had received previous warnings? With the coming into force of the Act on the Restraining Order in 2012 all these questions were resolved, for, as a result of the Act, article 265 was removed from the Criminal Code and incorporated in the Act on the Restraining order. This administrative Act prescribes that victims first have to procure a restraining order against their assailant from the Chief of Police, who is part of the police and the public prosecution service at the same time. It is only after the stalker has violated the restraining order that criminal prosecution can occur. This approach can, at best, be considered an indirect criminalization of stalking, because it requires one extra incident - a violation of the restraining order - before criminal investigation and prosecution can be initiated. This means that if the stalker abides by the conditions laid down in the restraining order, he cannot be held criminally liable for his previous misdeeds.

A second conclusion relates to the countries that had already enacted anti-stalking laws. Many of those countries have not remained inactive, but have amended their previously established laws during the past five years. In five jurisdictions the existing provisions were extended with particular elements (Belgium, Hungary, Italy) or the crime of stalking was introduced as an addition to criminal harassment (Malta, United Kingdom). Apparently, stalking is an elusive concept, challenging national legislators to capture the true essence of the crime, and sometimes forcing them to reconsider and alter laws that had only been in force for a couple of years. The elusive nature of the crime also shows in the fact that there are large differences in the manner in which the Member States have interpreted the crime. All 21 legal definitions differ from each other, and not just regarding the details. Because of their wide divergence, the remainder of the article will not focus on the constituent elements of all the different legal definitions, but highlight instead, what seem to be their most essential and overarching similarities and differences.

\section{Negative consequences for the victims}

In the 2012 article, certain trends had already been identified based on the comparison of the national anti-stalking laws in 13 EU Member States. Now that the number of countries with dedicated legislation has increased, resulting in more comparative material to analyze, some of these trends have become even more evident. One such trend is the inclusion of the negative consequences of the stalking for the victim as a constituent element of the crime, for instance, requiring the victim to have experienced fear as a consequence of the stalking.

This can be considered a questionable development, one that has generated much debate (see Owens 2016 for an overview). On the one hand there are academics who claim that 'fear' is an essential element of stalking. Without fear, the behavior might 
qualify as harassment, but not the crime of stalking. Allowing fear-neutral definitions would result in (over)criminalization of annoying behavior, thereby violating the ultimo ratio principle (criminalization as a measure of last resort).

Others, on the other hand, argue that an exclusive focus on fearful victims is unnecessarily restrictive, leaving certain groups of victims unprotected, especially in the phase where the stalking has not escalated yet and early criminal law intervention might prevent the further exacerbation of the situation and increase the likelihood of physical violence. In addition, other crimes do not require victims to have experienced subjective fear, and survey studies have indicated that the experience of fear is not seen as an indispensable feature of stalking in the perception of the general public either (for examples of such studies, see Dennison and Thomson 2005).

A consequence-specific provision excludes unusually equable or resilient victims, who do not feel threatened or frightened, from protection. Empirical research suggests that this may affect a large proportion of people who suffer from repeated stalking tactics. Of the 1430 respondents who had been identified as (potential) stalking victims on the basis of behavioral screening questions, only 36\% reported having experienced subjective fear (Owens 2016). Another survey study (Tjaden et al. 2000) also indicated that the percentage of self-defined stalking victims was substantially higher than the percentage using legislative-based criteria ( $12.1 \%$ versus $8.1 \%$ of the female participants; $6.2 \%$ versus $2.2 \%$ of the male participants). Over $60 \%$ of the self-defined victims did not meet the legal threshold, because they did not meet the legal fear requirement. Owen's (2016) results furthermore suggested gender differences, with women being much more fearful than men, making fear a gendered construct (see also Sheridan and Lyndon 2012; Wigman 2009; Langhinrichsen-Rohling 2012). The same gender-divide can be seen when it comes to cyberstalking (Pereira and Matos 2015).

Another problem is that once the negative consequences are included in the criminal provision, they need to be established in court and substantiated by evidence. This means, for instance, that in Germany, a prosecutor needs to prove that the behavior has 'seriously infringed on the lifestyle of the victim', while in Poland the stalking should have raised in the victim 'reasonable fear' or it should have 'significantly violated his peace'. In Italy, the stalking must have caused the victim to experience certain levels of anxiety or fear - assessed through forensic examination or externally discernable acts - it must have resulted in reasonable fear for the victim's safety or the safety of his or her relatives and loved-ones, or the stalking must have resulted in lifestyle changes (De Fazio 2011).

In contrast, there are also countries that do not require the victim to have experienced fear, distress or any other negative consequence as a result of the stalking. Such a consequence-neutral provision is to be preferred, at least from a victim's perspective, for it substantially alleviates the evidentiary burden: The public prosecutor does not have to prove what exact impact the stalking had on the victim. Especially when evidence of mental impact is required, this can be quite a challenge.

It is for these reasons, that in the United States, more and more states have objectified this element by introducing the reasonable person standard (National Center for Victims of Crime 2007, p. 48). It is no longer relevant whether the victim has actually suffered a certain level of fear - this does not have to be established in court — but whether a reasonable person would have suffered emotional stress because of the repetitive conduct. ${ }^{10}$

\footnotetext{
${ }^{10}$ An evaluation of the Czech anti-stalking law nevertheless revealed difficulties in legal practice with the requirement of the behavior being 'capable of raising fear for his/her life or health or the life or health of persons close to him' [italics - SvdA]. Even though the Czech legislator has objectified the fear requirement, the evaluation still reported problems in cases where the victims had not experienced subjective fear as well (Horakova 2012).
} 
Now at the time of the 2010 comparison, there was almost an equilibrium in Member States that had included or excluded the impact on the victim as a constituent element. Five Member States had a consequence-specific provision, ${ }^{11}$ while seven Member States were consequence-neutral. From the perspective of stalking victims, it is disconcerting to see that at least four Member States with new anti-stalking laws have now adopted a consequence-specific approach nonetheless (Croatia, Spain, Romania and Slovenia). Possibly, this preference for a consequence-specific provision is related to the fact that article 34 of the Council of Europe Convention also requires the victim to have experienced negative consequences as a result of the stalking ('causing her or him to fear for her or his safety').

\section{A limitative list of stalking tactics}

The EU Member States also diverge in their choice to include or exclude a list of possible stalking tactics in their criminal definition. While the inclusion of a list of behaviors can be useful in providing civilians and criminal justice authorities some guidance in their interpretation of the otherwise vague concept of stalking - thereby diminishing problems with the lex certa principle - this list should not be limited. Stalkers are creative and able to devise manners to circumvent a criminal offense that has incorporated a limitative list of stalking tactics. An exhaustive account of stalking behaviors furthermore limits the possibility to react to new technological developments that facilitate new forms of stalking (e.g., GPS tracking devices). Given the above limitations, it does not come as a surprise that a large majority of Member States have opted for a criminal definition without listing possible stalking tactics, or for a non-exhaustive list that merely serves as an example. Back in 2010, there were only two Member States that provided a limited list: Austria and the Czech Republic. In the meantime, their numbers have increased and now include Romania, Spain, Sweden, Slovenia, and Malta as well. ${ }^{12}$ In these countries, the lex certa argument and the desire to create unequivocal laws has prevailed over the need for flexibility.

\section{Aggravated sentencing in the case of 'qualified' victims}

Another trend is to make stalking against certain groups of 'qualified' victims subject to aggravated penalties. Possibly, this has to do with increased attention to violence against 'vulnerable victims' in general. The 2012 EU Victim Directive, for instance, stipulates that EU Member States have to develop extra protection measures for vulnerable victims.

Back in 2010, only Italy and Hungary had included a reference to qualified victims in their criminal anti-stalking provisions. In Italy, the maximum penalty increased if the victim was an ex-partner, a minor, a pregnant woman, or a person with disabilities. In Hungary, stalking a former spouse or registered partner or a person under his care, custody, supervision or

\footnotetext{
${ }^{11}$ These Member States included Malta, the UK and Hungary, albeit that their situation was somewhat more nuanced. These countries had created two primary offenses, both involving a course of conduct, but while the first offense did not have negative consequences included in its definition, the other (qualified) offense did require proof of the negative impact on the victim's life.

${ }^{12}$ In the case of Malta, only the new stalking provision contains a limitative enumeration of eligible behaviors. The harassment provision leaves room for other, non-exhaustive behaviors.
} 
treatment worked as an aggravating factor. While the Italian stipulation on qualified victims remains unchanged, the Hungarians implemented a new Criminal Code in 2013 that contained an altered anti-stalking provision. The group of qualified victims was expanded and now includes current spouses and current and former domestic partners as well. The Hungarian law, furthermore, stipulates that stalking involving abuse of a recognized position of trust, authority or influence over the victim also warrants aggravated sentencing.

Meanwhile, the practice to single out particular victims and imposing increased (maximum) penalties on whoever targets them is spreading quickly across Europe. Not only Member States that were in the process of drafting new legislation have adopted 'vulnerability' clauses, but also States with long-standing anti-stalking provisions have made changes to their laws. At this moment, a total of nine countries have included the quality of the victim as an aggravating factor in their anti-stalking provisions: Belgium, Croatia, the Czech Republic, France, Hungary, Malta, Slovakia, Slovenia, and Spain. Probably, there are even more Member States that prescribe higher sentences for qualified victims, but these prescriptions are not included in the stalking-provision itself (but could, for instance, be articulated in a general clause instead).

There does, however, seem to be a divide as to the exact victim characteristics that warrant the extra penalty. While in some countries the victims' physical and mental features and abilities are key - e.g., if the victim is a child, pregnant woman, or person suffering from physical or mental disabilities - other countries have introduced higher maximum penalties for perpetrators targeting victims with whom they share(d) a particular relationship. In these countries, stalking a(n) (ex) spouse or other (former) romantic partner, family members, or persons under their care or authority leads to elevated sentences.

Sometimes targeting a vulnerable victim not only influences the sentence, but it also changes the manner in which the crime has to be reported to the police. In Belgium, Spain and Italy, where stalking is usually only prosecuted upon the complaint of the victim, some vulnerable victims are exempted from this requirement. In their case, criminal prosecution can be initiated by the public prosecution service ex officio.

\section{From harassment to stalking}

A final development - one that is mostly confined to the common law countries - is to introduce a specific stalking offense in addition to the harassment provisions that had already been in place. For the purpose of this study, stalking and harassment are equated, with both crimes being classified as a criminal law solution to stalking, but in reality, there are differences between stalking and harassment. While both offenses usually require a course of conduct, harassment is often used as a more general, umbrella concept, one that includes stalking behavior, but that is not synonymous with stalking (e.g., Dennison and Thomson 2005). Furthermore, stalking has a more serious connotation than harassment, which can include milder forms of pestering as well (e.g., Owens 2016).

Ireland, Malta, England, and Wales are jurisdictions that initially tried to combat the new phenomenon of stalking with anti-harassment provisions. Although the harassment articles were always meant to cover all forms of harassment, including stalking, in practice victims of stalking were dissatisfied and felt that they were not taken seriously by the criminal justice system. ${ }^{13}$ In England and Wales (2012), and Malta (2015), the national legislators succumbed

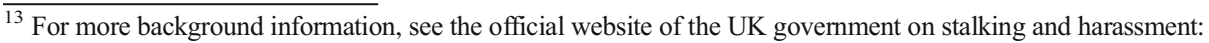
http://www.cps.gov.uk/legal (last accessed 31 May 2016).
} 
to public concerns and eventually introduced a specific stalking provision in addition to the anti-harassment laws. Under the offense of harassment, stalkers can only be prosecuted under a summary offense when the behavior falls short of causing fear of violence. This was considered an important lacuna in the English law. Thanks to the new offenses it is possible to prosecute a suspect for stalking and to impose more serious penalties, even when the course of conduct fails to inspire fear of violence in the victim, but only causes serious alarm or distress. In addition, it provides victims with more protection.

In Ireland, on the other hand, the Law Reform Commission recently concluded that existing harassment laws were adequate enough to deal with stalking. Still the debate has not been silenced by this decision, and lobbyists continue to campaign for a specific stalking offense. ${ }^{14}$ Whether the development of complementing harassment laws with dedicated anti-stalking provisions will spread to civil law jurisdictions that have placed the combat against stalking in the harassment key as well (e.g., France, Luxembourg, Hungary) remains to be seen.

\section{Conformity with article 34 of the Council of Europe Convention}

The Council of Europe Convention seems to have been an important catalyst in the progressive codification of stalking as a crime within the EU Member States. Since its coming into force in 2013, the number of countries with dedicated legislation has increased substantially and some (online) sources report of the direct link between the criminalization of stalking and the obligation stipulated in article 34 of the Convention (e.g., Pereira et al. 2017). The expectation is, therefore, that the other Member States - with the exception of Denmark - will soon follow suit (at least upon ratification).

Despite the fact that all ratifying countries have implemented anti-stalking laws, this does not mean that they are all $100 \%$ compliant with the Convention or its rationale. Some Member States have such a narrow definition of stalking that not all examples of stalking behavior mentioned in the explanatory report to the Convention are covered. The Romanian definition, for instance, only criminalizes stalking that consists of the repeated pursuit of an individual, the surveillance of this person's home, working place or other places, and unwanted (tele)communication with this person. Other stalking tactics mentioned in the Convention's explanatory report, such as vandalizing property or spreading untruthful information online, fall outside the scope of the Romanian definition. Similar difficulties may arise with other 'limitative' legal definitions, such as the Spanish, Austrian, Slovenian, and Czech definitions.

Another Member State that deserves closer attention is Sweden. A distinctive characteristic of the Swedish anti-stalking provision is that it appears to contain a limitative list of stalking tactics that consists solely of other crimes, such as assault, threat, unlawful entry, and vandalism. In other words, in Sweden, the constellation of behaviors that amount to stalking is exclusively made up of behaviors that had already been criminalized. If this interpretation is correct, it means that the criminal courts are not allowed to take 'mild' (in the sense of noncriminal) stalking tactics, such as making repetitive phone calls, sending unwanted gifts or posting in front of someone's home, into account. Although these seemingly innocuous behaviors have not been criminalized separately, research has demonstrated that stalkers make

\footnotetext{
${ }^{14}$ See, for instance, the news item of 26 November 2015, in which the director of Women's Aid, Margaret Martin, calls for the creation of a specific stalking offense: http://www.scottishlegal.com/2015/11/26/scots-antistalking-legislation-hailed-as-model-for-ireland/ (last accessed 31 May 2016).
} 
avail of them very often, and their repetitive nature and the specific circumstances in which they are applied makes them much more menacing than they would have been outside the stalking context. As a result, the Swedish provision may not reflect the full breadth and seriousness of the stalking experience that the victim has suffered.

Nevertheless, concluding that these Member States are in evident violation of article 34 of the Convention would be an overstatement. The signatory states have a margin of appreciation when it comes to their exact interpretation of the 'intentional conduct of repeatedly engaging in threatening conduct directed at another person' as stipulated in article 34. But judging by the examples provided in the Convention's explanatory report, some Member States' perception of what constitutes stalking does seem to deviate from the perception held by the initiators of the Convention.

\section{Conclusion}

All in all, it is safe to conclude that the European Member States have made significant progress and taken some long overdue steps in addressing the crime of stalking. Through this comparative analysis trends and best practices were identified. Some of these trends form a continuation of developments that had already been identified in the 2010 study. However, there are also entirely new developments - or developments that hitherto had been latently present, involving only one or two jurisdictions - that have only recently materialized in clearly distinguishable trends.

Keeping the methodological limitations of the study in mind, the analysis first demonstrated that since the coming into force of the Council of Europe Convention, there has been a sudden proliferation of Member States with dedicated anti-stalking laws. Within a timespan of only six years, their number has increased from 10 to 21 , and anecdotal evidence suggests that at least two more Member States are in the process of adopting anti-stalking legislation as well. The exact extent to which the Convention contributed to this proliferation is unclear, but there seems to be a causal connection between the coming into force of the Convention and the rapid increase in countries with dedicated legislation, a finding substantiated by several news items that explicitly link the two phenomena. It shows that the Convention was an important impetus to the criminalization of stalking on the European continent. In this respect, the Convention has been a success, and it will continue to be an important factor in the years to come, when the other Member States ratify the Convention.

When it comes to the question of the countries' full compliance with article 34, the first conclusion is that all countries that ratified the Convention have also criminalized stalking. From that point of view, there is no apparent violation of article 34 . Whether all of them adopted legal definitions that cover stalking to the full extent that the initiators of the Convention had in mind is debatable. The scope of certain anti-stalking laws with a limitative list of stalking tactics may be too narrow. However, the Convention's demarcation of stalking is not without controversy itself. The wordings of article 34 of the Convention can be considered somewhat ill chosen, especially regarding their emphasis on the consequences of the stalking for the victim. The requirement that the stalking should have caused the victim to fear for his or her safety perpetuates stereotypical 'classical stalking scripts' (Cuevas and Rennison 2016) and is a particularly high threshold that leaves many victims unduly unprotected. 
In addition to the arguments discussed in paragraph 2.1.2, there is an even more important argument for leaving the impact on the victim out of the equation. Arguably, it is not necessarily the causing of fear for physical safety that should be considered the core wrong of stalking, but the intrusive invasion of psychological space or mental privacy that warrants a criminal justice reaction (Guelke and Sorel 2016). In fact, there are multiple examples of stalking cases where no violence is threatened or feared, but where the victim's mind is nevertheless constantly occupied — and thereby debilitated — by the perpetual presence and invasive calls for attention of the stalker. Often the emotions experienced by the victims 'only' amount to feelings of alarm, anger or serious distress, rather than actual fear of physical harm, but when these emotions are experienced during a protracted period of time, pervading the victim's everyday life, they too can have an enormous negative impact on the victim's well-being. It is for this reason that it is troubling to see that many of the Member States with new legislation have opted for a consequence-specific definition of stalking, although their threshold is — thankfully — often lower than the one expressed in the Convention.

The trend to impose aggravated penalties in the case of vulnerable victims is also an interesting development. In the case of stalking, being labeled 'vulnerable' can have important implications. It can determine what penalty the offender will receive, but it can also impact victims' access to support services. Given these implications, the delineation between 'vulnerable' and 'normal' victims should not be taken lightly. From the legal definitions, however, it showed that there are large national discrepancies between the groups that are considered vulnerable, with some definitions focusing on the victims' mental and physical incapacities, and others on the (prior) stalker-victim relationship. Without a proper consideration of and justification for these choices, there is a risk that certain groups are unjustly overlooked or even discriminated against. Although an in-depth discussion of the concept of vulnerability and its relevance in the context of stalking falls outside the scope of this article, it does deserve further study.

As for the final two trends - an increased number of countries with exhaustive definitions and stalking laws in addition to harassment provisions - these have all been sufficiently discussed in the previous sections and will not be elaborated upon here. The unpredictable expressions of stalking, and the infamous ability of stalkers to find new ways to target their victims, demand that some flexibility is built into the criminal definition. From a victim's perspective, an exhaustive list of stalking tactics is therefore advised against. Adopting a non-exhaustive, illustrative list of tactics could be a way to reconcile lex certa with flexibility. The opposite is true for the trend to adopt special stalking laws in addition to harassment provisions. It is interesting to find that most common law jurisdictions that initially tried to combat stalking under the general flag of harassment have revised this choice and opted for specific legislation after all. Hopefully, this trend will soon inspire other harassment-oriented jurisdictions, because stalking and harassment, although related, are in the end different phenomena and warrant separate criminalization.

A final recommendation concerns the dearth of comparative and academic materials in the field of anti-stalking laws. Due to the lack of such sources, this study had to rely on a literal reading of national anti-stalking provisions. Additional sources, such as parliamentary documentation and case law could not be accessed. In combination with the linguistic limitations, this may have led to invalid conclusions. Because of these limitations, the current study is only explorative in nature and further research is highly recommended. 


\section{Appendix}

\section{Appendix 1. Criminal law definitions of stalking in the EU Member States}

\begin{tabular}{llll}
\hline Country & $\begin{array}{c}\text { Year of coming into force } \\
\text { /year of amendment }\end{array}$ & $\begin{array}{c}\text { Term used to } \\
\text { define stalking } \\
\text { 'Beharrliche } \\
\text { Verfolgung' }\end{array}$ & $\begin{array}{l}\text { Article } \\
\text { Austria }\end{array}$ \\
2006 & 107a Criminal Code
\end{tabular}

'(1) He who unlawfully insistently persecutes a person shall be punished with imprisonment of up to one year. (2) A person insistently persecutes if he, in a suitable way, with the intention of seriously affecting his way of life, during a longer period of time 1 . Seeks his physical proximity 2 . Uses telecommunication or other means of communication or third parties to get into contact with him 3. Orders goods or services for him by using his personal data 4. Prompts third parties to contact him by using his personal data.'
Belgium ${ }^{1}$
1998 (into force)
'Belaging'
442bis Criminal Code
2002 (amendment)

'He who harassed a person, while he knew or should have known that due to his behavior he would seriously disturb this person's peace, will be punished with a term of imprisonment of 15 days to two years and with a fine ranging from 50 euros to 300 euros or with one of those penalties. In case the acts mentioned in the first paragraph are committed against a person whose vulnerable situation as a consequence of age, pregnancy, illness or physical or mental disability or impairment, was apparent or known to the offender, the minimum penalty mentioned in the first paragraph is doubled. The behavior described in this article can only be prosecuted following a complaint by the person claiming to be harassed or, when a person mentioned in the second paragraph is concerned, of the public institutions or entities mentioned in article 43 of the act of 26 November 2011 to change the Criminal Code in order to criminalize abuse of the vulnerable position of persons, and extend the criminal law protection of vulnerable persons against abuse.'

\section{Bulgaria $^{1}$ \\ No criminalization}

Croatia $^{1}$

'(1) Whoever persistently and over a long period of time follows or spies on another, or establishes or seeks to establish unwanted contact with another, or intimidates another in some other way and, by doing so, provokes anxiety in him/her or causes him/her to fear for his/her safety or the safety of persons close to him/her shall be sentenced to imprisonment for a term of up to one year. (2) If the offense referred to in paragraph 1 of this Article is committed against the current or former spouse or cohabitant or same-sex partner, a person with whom the perpetrator was in an intimate relationship or a child, the perpetrator shall be sentenced to imprisonment for a term of up to three years. (3) Unless it was committed against a child, the criminal offense referred to in paragraphs 1 and 2 of this Article shall be prosecuted upon request.'

\section{Cyprus $^{3}$}

No criminalization, but Ministry of Justice working on a bill as the result of CoE Convention

$\begin{array}{lll}\text { Czech Republic }^{2} & 2010 & \begin{array}{l}\text { Nebezpečné } \\ \text { pronásledováni' }\end{array}\end{array}$

'(1) Whoever pursues another in long term by a) threatening with bodily harm or another harm to him/her or to persons close to him/her, b) seeks his/her personal presence or follows him/her, c) persistently contacts him/her by means of electronic communications, in writing or in another way, d) abuses his/her personal data for the purpose of gaining personal or other contact, and this conduct is capable of raising reasonable fear for his/her life or health or lives or health of persons close to him/her, shall be sentenced to imprisonment for up to one year or to prohibition of activity. (2) An offender shall be sentenced to imprisonment for six months to three years, if he/she commits the act referred to in Sub-section (1) a) against a child or a pregnant woman, b) with a weapon, or c) with at least two persons.'

\section{Denmark $^{3}$}

Estonia

$$
\text { No criminalization }
$$

No criminalization

Finland $^{2}$

\section{'Vainoaminen'}

Chapter 25 Section 7(a) Criminal
Code
'A person who repeatedly threatens, observes, contacts or in another comparable manner unjustifiably stalks another so that this is conducive toward instilling fear or anxiety in the person being stalked, shall, unless an 
equally or a more severe penalty is provided elsewhere in law for the act, be sentenced for stalking to a fine or to imprisonment for at most two years.'
France $^{1}$
2014
'Harcèlement moral'
222-33-2 Criminal Code

'To harass others by words or repetitive behaviors that have the purpose or effect of degrading another person's working conditions, likely to affect this person's rights and dignity, to alter his/her physical or mental health or to jeopardize his professional future, is punishable by two years' imprisonment and a $€ 30,000$ fine. (1) Harassing one's spouse, civil partner or cohabitee by words or repetitive behaviors that have the purpose or effect of deteriorating this person's living conditions, resulting in an impairment of physical or mental health, is punishable by three years imprisonment and a $€ 45,000$ fine when these acts have caused a total incapacity to work of eight days or less or have not resulted in any incapacity to work, and five years' imprisonment and $€ 75,000$ fine when they have caused a total incapacity to work for more than eight days. The same penalties are incurred when the offense is committed by a former spouse or former cohabitee of the victim, or a former civil partner. (2) To harass a person by words or repetitive behaviors that have the purpose or effect of deterioration this person's living conditions, resulting in an impairment of physical or mental health is punishable by one year imprisonment and a $€ 15,000$ fine when these acts have caused a total incapacity to work for eight days or less or resulted in no incapacity to work.

The facts mentioned in the first paragraph are punishable by two years' imprisonment and a fine of $€$ 30,000: (1) When they have caused a total incapacity to work for more than eight days;(2) When they have been committed against a minor under 15 years; (3) When they were committed on a person whose particular vulnerability, due to age, illness, infirmity, a physical or mental disability or to pregnancy, is apparent or known to the perpetrator; (4) When they were committed by the use of a public online communication service.

The facts mentioned in the first paragraph are punishable by three years imprisonment and a $€ 45,000$ fine if committed in two of the circumstances referred to in 1 to $4^{\circ}$.'
Germany $^{2}$
2007
'Nachstellung'
238 Criminal Code

'(1) Whosoever unlawfully stalks another person by: 1) seeking his proximity; 2) trying to establish contact with him by means of telecommunications or other means of telecommunication or through third persons; 3 ) abusing his personal data for the purpose of ordering goods or services for him or causing third persons to make contact with him; 4) threatening him or a person close to him with loss of life or limb, damage to health, or deprivation of freedom, or 5) committing similar acts, and thereby seriously infringes his lifestyle shall be liable to imprisonment of not more than three years or a fine. (2) The penalty shall be three months to five years if the offender places the victim, a relative of or another person close to the victim in danger of death or serious injury. (3) If the offender causes the death of the victim, a relative of or another person close to the victim the penalty shall be imprisonment from one to ten years. (4) Cases under subsection (1) above may only be prosecuted upon request unless the prosecuting authority considers propio motu that prosecution is required because of special public interest.'

Greece $^{1}$

No criminalization

Hungary ${ }^{2}$

\section{8 (into force) \\ 2013 (amendement)}

'Zaklatás'

\section{2 of the Criminal Code}

'(1) Any person who engages in conduct intended to intimidate another person, to disturb the privacy of or to upset, or cause emotional distress to another person arbitrarily, or who is engaged in the pestering of another person on a regular basis, is guilty of a misdemeanor punishable by imprisonment not exceeding one year, insofar as the act did not result in a more serious criminal offense. (2) Any person who, for the purpose of intimidation: a) conveys the threat of force or public endangerment intended to inflict harm upon another person, or upon a relative of this person, or

b) giving the impression that any threat to the life, physical integrity or health of another person is imminent, is guilty of a misdemeanor punishable by imprisonment not exceeding two years.

(3) Any person who commits the act of harassment: a) against his/her spouse or former spouse, or against his/her domestic partner or former domestic partner, b) against a person under his/her care, custody, supervision or treatment, or $c$ ) if abuse is made of a recognized position of trust, authority or influence over the victim, shall be punishable by imprisonment not exceeding two years in the case provided for in Subsection (1), or by imprisonment not exceeding three years for a felony in the case provided for in Subsection (2).'

Ireland $^{2}$ 1997

'Harassment'

Section 10 of the Non-fatal Offenses against the Person Act

'(1) Any person who, without lawful authority or reasonable excuse, by any means including by use of the telephone, harasses another by persistently following, watching, pestering, besetting or communicating with him or her, shall be guilty of an offense. (2) For the purposes of this section a person harasses another where (a) he or she, by his or her acts intentionally or recklessly, seriously interferes with the other's peace and privacy or causes alarm, distress or harm to the other, and(b) his or her acts are such that a reasonable person 
would realize that the acts would seriously interfere with the other's peace and privacy or cause alarm, distress or harm to the other. (3) Where a person is guilty of an offense under subsection (1), the court may, in addition to or as an alternative to any other penalty, order that the person shall not, for such period as the court may, specify, communicate by any means with the other person or that the person shall not approach within such distance as the court shall specify of the place of residence or employment of the other person. (4) A person who fails to comply with the terms of an order under subsection (3) shall be guilty of an offense. (5) If on the evidence the court is not satisfied that the person should be convicted of an offense under subsection (1), the court may nevertheless make an order under subsection (3) upon an application to it in that behalf if, having regard to the evidence, the court is satisfied that it is in the interests of justice so to do. (6) A person guilty of an offense under this section shall be liable (a) on summary conviction to a fine not exceeding $£ 1500$ or to imprisonment for a term not exceeding 12 months or to both, or (b) on conviction on indictment to a fine or to imprisonment for a term not exceeding 7 years or to both.'

\section{Italy 2009 (into force) 'Atti persecutori' 612bis Criminal Code}

'Unless the act constitutes a more serious crime, anyone who, repeatedly threatens or harasses another person in such a way as to cause in her/him a serious and constant state of anxiety or fear, or to produce reasonable fear for his or her safety or for that of a close relative or of a person bound by an affective relationship, or to force the victim to change his/her lifestyle, shall be punished with imprisonment from six months to five years. The penalty is increased if the offense is committed by a legally separated or divorced spouse or by a person who is bound to the victim by an affective relationship or when the offense is committed by phone or electronic communication. The penalty is increased by up to its half if the offense is committed against a minor, a pregnant woman or a person with disabilities as expressed in art. 3 of the Law 5 February 1992, n. 104, or by a person with weapons or under false appearances. The crime is punishable upon complaint of the victim. The deadline for applying for the lawsuit is six months. The complaint can be voluntarily dismissed, but the dismissal must be formal and must happen in the trial. In any case the complaint cannot be dismissed when the offense is committed by repeated threats, as specified in Article 612. The crime is immediately prosecuted if the offense is committed against a minor or a person with disabilities as expressed by art. 3 of the Law 5 February 1992, n. 104 and when the fact is connected with another offense automatically subjected to prosecution.'

Latvia $^{1}$

No criminalization, but currently working on a bill as a result of the CoE Convention

Lithuania $^{1}$

No criminalization

Luxembourg $^{3}$ 'Harcèlement
obsessionel'

\section{2-2 Criminal Code}

'Anyone who repeatedly harassed a person while he knew or should have known that by such conduct he would seriously affect the tranquility of that person, shall be punished with imprisonment of 15 days to two years and a fine of 251 to 3000 euro, or one of these penalties. The offense in this article shall be prosecuted on the complaint of the victim, his legal representative, or his assigns.'
Malta $^{2}$
2005 (harassment)
'Stalking'
251AA Criminal Code

'(1) A person who: (a) pursues a course of conduct in breach of article 251A(1), and (b) the course of conduct amounts to stalking, shall be guilty of an offense under this article. (2) For the purposes of paragraph $(b)$ of sub-article (1) of this article and article 251BA(1)(a), a person's course of conduct

amounts to stalking of another person if: $(a)$ it amounts to harassment of that person, $(b)$ it constitutes any of the acts mentioned in sub-article (3), and (c) the person, whose course of conduct it is, knows or ought to know that the course of conduct amounts to harassment of the other person. (3) The following acts shall be deemed to be acts of stalking: (a) following a person,

(b) contacting, or attempting to contact, a person by any means, (c) publishing, by any means, any statement or other material (i) relating or purporting to relate to a person, or (ii) purporting to originate from a person, $(d)$ monitoring the use by a person of the internet, email or any other form of electronic communication, $(e)$ loitering in any place, whether public or private, $(f)$ interfering with any property in the possession of a person, $(g)$ watching or spying on a person. (4) A person guilty of an offense under this article shall be liable to the punishment of imprisonment for a term from 6 to 12 months or to a fine (multa) not exceeding ten thousand euro $(10,000)$, or to both such fine and imprisonment: Provided that the punishment shall be increased by one degree when the offense is committed against any person mentioned in article 222(1).'
The Netherlands ${ }^{1}$
2000
'Belaging'
285b Criminal Code

'(1) He who unlawfully, systematically, intentionally intrudes upon another person's privacy with the aim of forcing that person to do something, to refrain from doing something, to tolerate something or to instil fear in that person, is liable, as guilty of stalking, to a prison term with a maximum of three years or a fine of the 
fourth category. (2) Prosecution can only occur on the complaint of the person against whom the crime was committed.'
Poland $^{1}$
'Stalking'
190a Criminal Code

'(1) He who by the persistent harassment of another person or a person's near ones raises in him a reasonable fear or significantly violates his privacy shall be liable to an imprisonment of up to 3 years. (2) He who, pretending to be another person, uses his image or other personal data in order to cause material or personal damage, shall be subjected to the same penalty. (3) If the act specified in $\S 1$ or 2 results in a suicide attempt by the victim, the perpetrator is liable to an imprisonment of 1 to 10 years. (4) Prosecution of the crime specified in $\S 1$ or 2 occurs at the request of the victim.'
Portugal $^{1}$
2015
'Perseguição'
154-A Criminal Code

'(1) Every person who, in a continuous manner, persecutes or harasses another person, by any direct or indirect means, in a way that can reasonably cause fear or distress or jeopardize this person's freedom is guilty of an offense punishable with 3 years' imprisonment or a fine, unless a more serious penalty applies by force of another legal provision. (2) The attempt is punishable. (3) In the cases provided for in paragraph 1 , accessory penalties of prohibition of contacts can be issued against the defendant for a period of 6 months up to 3 years and mandatory attendance of specific programmes for prevention of the acts of persecution. (4) The accessory penalty of prohibition of contacts with the victim shall include prohibition of approaching the house or the workplace of the victim. The defendant's compliance with these conditions shall be monitored by electronic surveillance devices. (5) The criminal proceedings depend on an official complaint.'
Romania $^{2}$
2014
'Hartuirea'
208 Criminal Code

(1) The act of an individual who repeatedly, with or without a right or legitimate interest, pursues an individual or supervises their domicile, working place or other places attended by the latter, thus causing to them a state of fear, shall be punishable by no less than 3 and no more than 6 months of imprisonment or by a fine. (2) Making of phone calls or communications through remote communication devices which, through their frequency or content, cause a state of fear to an individual, shall be punishable by no less than 1 and no more than 3 months of imprisonment or by a fine, unless such act represents a more serious offense. (3) Criminal action shall be initiated based on a prior complaint filed by the victim.

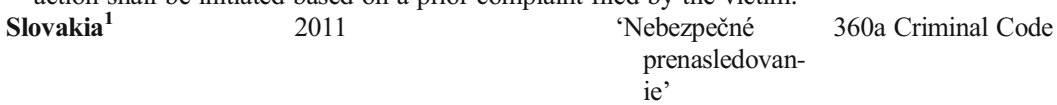

'(1) Any person who continually pursues another to an extent that may give rise to justifiable fear for his/her life or health, or the life or health of someone close to this person, or significantly worsens his/her quality of life by a) threating with bodily harm or other injury to him/her or to someone close to him/her, b) seeking this person's physical proximity or pursuing him/her, c) contacting him/her against his/her will through a third party, through an electronic communication service, in writing or another manner, (d) exploiting this person's personal data for the purpose of obtaining personal or other contact or e) otherwise limiting him/her in his/her usual way of life, shall be liable to a term of imprisonment of up to one year. (2) The offender shall be liable to imprisonment between six months and three years, if he commits the offense referred to in paragraph 1 a) against a protected person, b) in a serious manner, c) with specific motives, d) in public.'
Slovenia $^{1}$
2015
'Zalezovanje'
134a Criminal Code

'(1) Whoever through repetitive observation, following or an intrusive attempt to engage in direct contact or contact through the means of electronic communication stalks another person or his relative and thereby causes fright or feelings of threat in another person or his relative, shall be punished by a fine or sentenced to imprisonment up to two years. (2) If the stalked person is a minor or a helpless person, the perpetrator shall be punished with a fine or sentenced to imprisonment of up to three years. (3) The prosecution of the offense under paragraph 1 and 2 of this article shall be initiated upon a complaint.'
Spain ${ }^{1}$
2015
'Stalking'
172ter Criminal Code

'(1) With an imprisonment of three months to two years or a fine of 6 to 24 months shall be punished he who harasses a person by insistently, repeatedly, and without being lawfully authorized, displays any of the following behaviors, thereby seriously altering the development of this person's daily life: 1) Watching, pursuing or searching her physical proximity; 2) Contacting or trying to contact her through any media, or through third parties; 3) Purchasing products or goods, by misusing her personal data, or hiring services, or having third parties come in contact with her; 4) Violating her freedom or property, or violate freedom or property of another person close to her. If a particularly vulnerable person is concerned, because of age, illness or other circumstances, imprisonment of six months to two years shall be imposed. (2) When the injured party concerned is one of the persons referred to in paragraph 2 of Article 173, a prison sentence of one to two years, or community service of 60 to 120 days shall be imposed. In this case, the complaint referred to in paragraph 4 of this article is not required. (3) The penalties provided for in this article shall 
be imposed regardless of the penalties imposed because of the crimes that can constitute the stalking. (4) The facts described in this article will only be prosecuted on the complaint of the aggrieved person or his legal representative.'

$\begin{array}{llc}\text { Sweden }^{1} & 2011 \text { (into force) } & \text { 'Olaga förföljelse' } \\ & 2016 \text { (amendment) } & \text { or 'stalkning' }\end{array}$

'Anyone who harasses a person through illegal acts constituting: 1) assault in accordance with chapter $3 \S 5$ or attempts to commit such a crime that is not considered a minor offense, 2) duress in accordance with chapter 4 $\S 4$, first paragraph; 3) unlawful threats in accordance with chapter $4 \S 5$, first paragraph; 4) unlawful entry or trespassing in accordance with chapter $4 \S 6 ; 5$ ) degrading photo shooting in accordance with chapter $4 \S 6$ a; $6)$ identity theft in accordance with chapter $4 \S 6$; 7) harassment in accordance with chapter $4 \S 7$; 8) sexual harassment in accordance with chapter $6 \S 10 ; 9$ ) vandalism of property in accordance with chapter $12 \S 1$ or attempts to commit such crime; 10) inflicting damage in accordance with chapter $12 \S 2$, first paragraph; 11) violation of a restraining order in accordance with $\S 24$ Act (1988:688) on restraining orders; if each of the acts have been a repeated violation of the person's integrity, shall be sentenced for stalking to imprisonment not exceeding four years.'

United Kingdom ${ }^{2}$

England \& Wales

1997 (harassment) 2012 'Stalking' (stalking)
Article 2a and Article 4a Protection from Harassment Act 1997

Article 2a (Offenses in relation to stalking):

'(1) A person is guilty of an offense if (a) the person pursues a course of conduct in breach of section $1(1),{ }^{15}$ and (b) the course of conduct amounts to stalking. (2) For the purposes of subsection (1)(b) (and section $4 \mathrm{~A}(1)(\mathrm{a}))$ a person's course of conduct amounts to stalking of another person if (a) it amounts to harassment of that person, (b) the acts or omissions involved are ones associated with stalking, and (c) the person whose course of conduct it is knows or ought to know that the course of conduct amounts to harassment of the other person. (3) The following are examples of acts or omissions which, in particular circumstances, are ones associated with stalking (a) following a person, (b) contacting, or attempting to contact, a person by any means, (c) publishing any statement or other material (i) relating or purporting to relate to a person, or (ii) purporting to originate from a person, (d) monitoring the use by a person of the internet, email or any other form of electronic communication, (e) loitering in any place (whether public or private), (f) interfering with any property in the possession of a person, (g) watching or spying on a person. (4) A person guilty of an offense under this section is liable on summary conviction to imprisonment for a term not exceeding 51 weeks, or a fine not exceeding level 5 on the standard scale, or both. (5) In relation to an offense committed before the commencement of section 281(5) of the Criminal Justice Act 2003, the reference in subsection (4) to 51 weeks is to be read as a reference to six months.

(6) This section is without prejudice to the generality of section 2."

Article 4A (Stalking involving fear of violence or serious alarm or distress)

(1) A person ("A") whose course of conduct (a) amounts to stalking, and (b) either (i) causes another ("B") to fear, on at least two occasions, that violence will be used against B, or (ii) causes B serious alarm or distress which has a substantial adverse effect on B's usual day-to-day activities, is guilty of an offense if A knows or ought to know that A's course of conduct will cause B so to fear on each of those occasions or (as the case may be) will cause such alarm or distress.

(2) For the purposes of this section A ought to know that A's course of conduct will cause B to fear that violence will be used against $\mathrm{B}$ on any occasion if a reasonable person in possession of the same information would think the course of conduct would cause B so to fear on that occasion. (3) For the purposes of this section A ought to know that A's course of conduct will cause B serious alarm or distress which has a substantial adverse effect on B's usual day-to-day activities if a reasonable person in possession of the same information would think the course of conduct would cause B such alarm or distress. (4) It is a defense for A to show that (a) A's course of conduct was pursued for the purpose of preventing or detecting crime, (b) A's course of conduct was pursued under any enactment or rule of law or to comply with any condition or requirement imposed by any person under any enactment, or (c) the pursuit of A's course of conduct was reasonable for the protection of A or another or for the protection of A's or another's property. (5) A person guilty of an offense under this section is liable (a) on conviction on indictment, to imprisonment for a term not exceeding 5 years, or a fine, or both, or (b) on summary conviction, to imprisonment for a term not exceeding 12 months, or a fine not exceeding the statutory maximum, or both. (6) In relation to an offense committed before the commencement of section

${ }^{15}$ Article 1(1) of the Protection from Harassment Act 1997 contains the prohibition of harassment. Harassment is defined as 'a course of conduct (a) which amounts to harassment of another, and

(b) which he knows or ought to know amounts to harassment of the other'. 
154(1) of the Criminal Justice Act 2003, the reference in subsection (5)(b) to 12 months is to be read as a reference to 6 months. (7) If on the trial on indictment of a person charged with an offense under this section the jury find the person not guilty of the offense charged, they may find the person guilty of an offense under section 2 or $2 \mathrm{~A}$. (8) The Crown Court has the same powers and duties in relation to a person who is by virtue of subsection (7) convicted before it of an offense under section 2 or 2A as a magistrates' court would have on convicting the person of the offense. (9) This section is without prejudice to the generality of section 4.

1997 (harassment) $2010 \quad$ 'Stalking' (stalking)

Section 39 of the Criminal Justice and Licensing (Scotland) Act 2010

'(1) A person ("A") commits an offense, to be known as the offense of stalking, where A stalks another person ("B").

(2) For the purposes of subsection (1), A stalks B where (a) A engages in a course of conduct, (b) subsection (3) or (4) applies, and (c) A's course of conduct causes B to suffer fear or alarm. (3) This subsection applies where A engages in the course of conduct with the intention of causing B to suffer fear or alarm. (4) This subsection applies where A knows, or ought in all the circumstances to have known, that engaging in the course of conduct would be likely to cause B to suffer fear or alarm. (5) It is a defense for a person charged with an offense under this section to show that the course of conduct (a) was authorized by virtue of any enactment or rule of law, (b) was engaged in for the purpose of preventing or detecting crime, or (c) was, in the particular circumstances, reasonable.

(6) In this section "conduct" means (a) following B or any other person, (b) contacting, or attempting to contact, B or any other person by any means, (c) publishing any statement or other material (i) relating or purporting to relate to B or to any other person, (ii) purporting to originate from B or from any other person, (d) monitoring the use by B or by any other person of the internet, email or any other form of electronic communication, (e) entering any premises, (f) loitering in any place (whether public or private), $(\mathrm{g})$ interfering with any property in the possession of B or of any other person, (h) giving anything to B or to any other person or leaving anything where it may be found by, given to or brought to the attention of B or any other person, (i) watching or spying on B or any other person, (j) acting in any other way that a reasonable person would expect would cause B to suffer fear or alarm, and "course of conduct" involves conduct on at least two occasions. (7) A person convicted of the offense of stalking is liable (a) on conviction on indictment, to imprisonment for a term not exceeding 5 years, or to a fine, or to both, (b) on summary conviction, to imprisonment for a term not exceeding 12 months, or to a fine not exceeding the statutory maximum, or to both. (8) Subsection (9) applies where, in the trial of a person ("the accused") charged with the offense of stalking, the jury or, in summary proceedings, the court (a) is not satisfied that the accused committed the offense, but (b) is satisfied that the accused committed an offense under section 38(1). (9) The jury or, as the case may be, the court may acquit the accused of the charge and, instead, find the accused guilty of an offense under section 38(1).

\footnotetext{
${ }^{1}$ Legal definition translated (and information confirmed) by a native legal expert

${ }^{2}$ (Semi)official (translation of) legal definition available on the internet

${ }^{3}$ Information found or legal definition translated by non-native author. Interpret with care
}

\section{Appendix 2. Online English/translated Criminal Codes or Acts containing stalking}

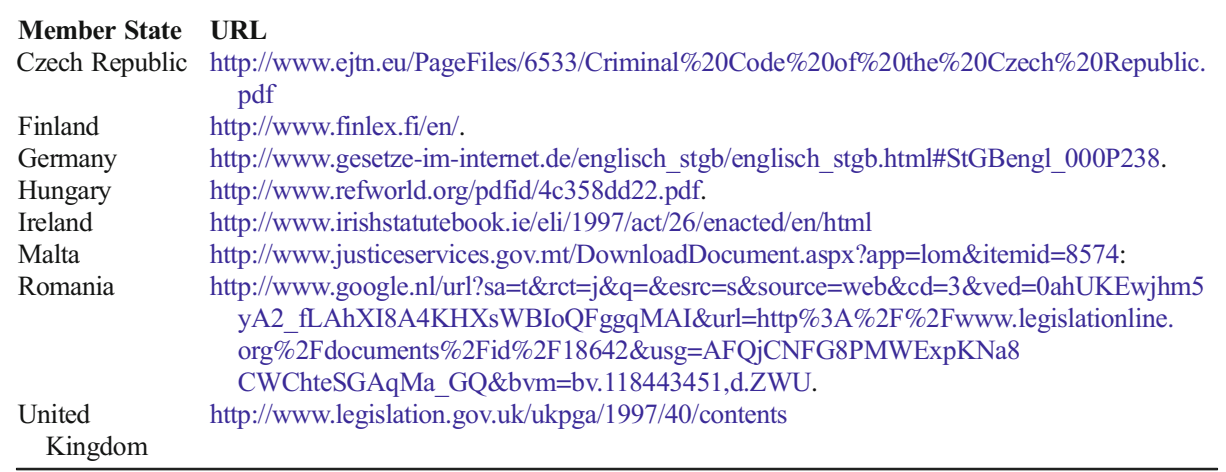


Open Access This article is distributed under the terms of the Creative Commons Attribution 4.0 International License (http://creativecommons.org/licenses/by/4.0/), which permits unrestricted use, distribution, and reproduction in any medium, provided you give appropriate credit to the original author(s) and the source, provide a link to the Creative Commons license, and indicate if changes were made.

\section{References}

Ashworth, A., Zedner, L., \& Tomlin, P. (2013). Prevention and the limits of the criminal law. Oxford: Oxford University Press.

Balzan, J. (2014). Stalking to be made specific criminal offence. MaltaToday, 12 June 2014. Retrieved from http://www.maltatoday.com.mt/news/national/39900/stalking to be made specific criminal offence\#. WNkEy4dMRzM.

Cuevas, C. A., \& Rennison, C. M. (2016). Perceptions of stalking victimization among behaviorally defined victims. Examining factors that influence self-identification. In T. C. Hart \& E. I. Troshynsky (Eds.), The Wiley handbook on the psychology of violence (pp. 158-178). Chichester: Wiley.

De Fazio, L. (2009). The legal situation on stalking among the European member states. European Journal on Criminal policy and Research, 15(3), 229-242.

De Fazio, L. (2011). Criminalization of stalking in Italy: One of the last among the current European member states' anti-stalking laws. Behavioral Sciences \& the Law, 29(2), 317-323.

Dennison, S. M., \& Thomson, D. M. (2005). Criticisms or plaudits for stalking laws? What psychological research tell us about proscribing stalking. Psychology, Public Policy and Law, 11(3), 384-406.

Finland Times (2015). Incidents of stalking increase in 2014. Finland Times, 2 February 2015. Retrieved from http://www.finlandtimes.fi/national/2015/02/02/13879/Incidents-of-stalking-increase-in-2014.

Guelke, J. \& Sorel, T. (2016). Violations of privacy and law: The case of stalking. Law, Ethics and Philosophy. (4), 32-60

Horakova, M. (2012). Stalking, the new phenomenon of the Czech criminal law. In D. Pavelkova, J. Strouhal, \& M. Pasekova (Eds.), Advances in economics, risk management, political \& law science (pp. 171-177). Zlin: Tomas Bata University.

Kelly, L., Hagemann-White, C., \& Römkens, R. (2010). Feasibility study to assess the possibilities, opportunities and needs to standardise national legislation on violence against women, violence against children and sexual orientation violence. Luxembourg: Publications Office of the European Union.

Kraenz, N. (2008). Der strafrechtliche Schutz des Persönlichkeitsrechts. Nomos Universitätsschriften (Recht).

Langhinrichsen-Rohling, J. (2012). Gender and stalking: Current intersections and future directions. Sex Roles, $66(5 / 6), 418-426$.

Modena Group on Stalking. (2007). Protecting women from the new crime of stalking: A comparison of legislative approaches within the European Union. Modena: University of Modena and Reggio Emilia.

Mullen, P. E., Pathé, M., \& Purcell, R. (2001). Stalking: New constructions of human behaviour. Australian and New Zealand Journal of Psychiatry, 35, 9-16.

National Center for Victims of Crime. (2007). The model stalking code revisited: Responding to the new realities of stalking. Washington DC: National Center for Victims of Crime.

Owens, J. G. (2016). Why definitions matter: Stalking victimization in the United States. Journal of Interpersonal Violence, 31(12), 2196-2226.

Pereira, F., \& Matos, M. (2015). Cyber-stalking victimization: What predicts fear among Portuguese adolescents? European Journal on Criminal Policy and Research, 21(2), 1-18.

Pereira, C., Matos, M., \& Antunes, C. (2017). Pathways towards new criminalisation: The case of stalking in Portugal. European Journal on Criminal Policy and Research, 1-10.

Sheridan, L., \& Lyndon, A. E. (2012). The influence of prior relationship, gender, and fear on the consequences of stalking victimization. Sex Roles, 66(5/6), 340-350.

Tjaden, P., Thoennes, N., \& Allison, C. J. (2000). Comparing stalking victimisation from legal and victim perspectives. Violence and Victims, 15, 7-22.

Valente, L. (2014). Stalking, cyberstalking e casamento forçado vão ser crimes. Observador, 4 September 2014. Retrieved from http://observador.pt/2014/09/04/stalking-cyberstalking-e-casamento-forcado-vao-ser-crimes/.

Van der Aa, S. (2010). Stalking in the Netherlands. Nature and prevalence of the problem and the effectiveness of anti-stalking measures. diss. Antwerpen: Maklu.

Van der Aa, S., \& Römkens, R. (2012). The state of the art in stalking legislation: Reflections on European developments. European Criminal Law Review, 3(2), 232-256.

Wigman, S. A. (2009). Male victims of former-intimate stalking: A selected review. International Journal of Men's Health, 8(2), 101-115. 